\title{
Predictors of response to cardiac resynchronization therapy: the holy grail of electrophysiology
}

\author{
Haisam Ismail • Amgad N. Makaryus
}

Received: 30 November 2009/Accepted: 4 December 2009/Published online: 30 December 2009

(C) Springer Science+Business Media, B.V. 2009

Cardiac Resynchronization Therapy (CRT) has been found to improve quality of life, reduce heart-failure related hospitalizations, and prolong survival in patients with New York Heart Association (NYHA) class III or IV heart failure and electrocardiographic evidence of ventricular dyssynchrony [1-2]. CRT is currently an indispensable mode of treatment for the increasing number of eligible persons with severe heart failure [3, 4]. Although there is significant success of CRT, there are a significant number of patients who do not show improvement with CRT [2, 5-7]. It is reported in many clinical trials such as the Multicenter InSync Randomized Clinical Evaluation (MIRACLE) that $34 \%$ of individuals eligible for CRT did not benefit based on a heart failure clinical composite score [2, 5, 7-9]. These so called "nonresponders" have spurred research into identifying potential responders to CRT before device implantation. Important echocardiographic parameters measuring ventricular dyssynchrony using tissue doppler imaging (TDI) among other methods, as well as important parameters such as device lead placement

Editorial comment on the article of Pavlopoulos and Nihoyannopoulos (doi: 10.1007/s10554-009-9523-5).

H. Ismail · A. N. Makaryus ( $\square)$

Department of Cardiology, North Shore University

Hospital, 300 Community Drive, Manhasset,

NY 11030, USA

e-mail: amakaryu@nshs.edu and level of scar formation are important when determining ideal patients for CRT [8-16]. Several single-center studies have established different echocardiographic parameters to distinguish CRT responders from non-responders. Furthermore, in the multicenter study of Predictors of Response to CRT (PROSPECT), echocardiographic measures of ventricular dyssynchrony such as left ventricular endsystolic volume (LVESV) and septal-posterior wall motion delay (SPWMD) were used to predict responsiveness to CRT [16]. It was shown that despite promising data from small single-center studies, echocardiographic measures of ventricular dyssynchrony fail to have enough predictive clinical merit to be established as selection criteria for CRT [16].

In the current report by Pavlopoulos and Nihoyannopoulos, the authors review both echocardiographic and clinical parameters for predicting response to CRT. This review article highlights the point that besides echo based parameters, perhaps clinical parameters such as the medical history of whether atrial fibrillation exists, or ischemic versus non-ischemic cardiomyopathy may help. Furthermore, incorporating more advanced imaging modalities such as cardiac magnetic resonance imaging may help overcome certain limitations of echocardiography. It has been shown in the multicenter study PROSPECT that echo-based dyssynchrony is not sufficient and failed to predict responsiveness to CRT. Therefore, it is imperative in the future as the 
current paper proposes, that an overall and complete approach combining not only echo parameters of dyssynchrony but also clinical and other imaging modality parameters be undertaken to evaluate and predict responsiveness to CRT because there are many more important variables besides electrical dyssynchrony that appear to contribute to outcomes in these patients. Therefore, the search for the holy grail of prediction of responsiveness to CRT continues!

\section{References}

1. Abraham WT, Fisher WG, Smith AL, Delurgio DB, Leon AR, Loh E, Kocovic DZ, Packer M, Clavell AL, Hayes DL, Ellestad M, Trupp RJ, Underwood J, Pickering F, Truex C, McAtee P, Messenger J, MIRACLE Study Group, Multicenter InSync Randomized Clinical Evaluation (2002) Cardiac resynchronization in chronic heart failure. N Engl J Med 346(24):1845-1853

2. Bristow MR, Saxon LA, Boehmer J, Krueger S, Kass DA, De Marco T, Carson P, DiCarlo L, DeMets D, White BG, DeVries DW, Feldman AM, For the COMPANION Investigators (2004) Cardiac-resynchronization therapy with or without an implantable defibrillator in advanced chronic heart failure. N Engl J Med 350:2140-2150

3. Cleland JG, Daubert JC, Erdmann E, Freemantle N, Gras D, Kappen-berger L, Tavazzi L, For the Cardiac Resynchronization-Heart Failure (CARE-HF) Study Investigators (2005) The effect of cardiac resynchronization on morbidity and mortality in heart failure. $\mathrm{N}$ Engl $\mathrm{J}$ Med 352:1539-1549

4. Ho KKL, Pinsky JL, Kannel WB, Levy D (1993) The epidemiology of heart failure: the Framingham study. J Am Coll Cardiol 22(Suppl A):6A-13A

5. Bax JJ, Marwick TH, Molhoek SG, Bleeker GB, Van Erven L, Boersma E, Steendijk P, van der Wall EE, Schalij MJ (2003) Left ventricular dyssynchrony predicts benefit of cardiac resynchronization therapy in patients with endstage heart failure before pacemaker implantation. Am J Cardiol 92(10):1238-1240

6. Yu CM, Fung WH, Lin H, Zhang Q, Sanderson JE, Lau CP (2003) Predictors of left ventricular reverse remodeling after cardiac resynchronization therapy for heart failure secondary to idiopathic dilated or ischemic cardiomyopathy. Am J Cardiol 91:684-688

7. Young JB, Abraham WT, Smith AL, Leon AR, Lieberman R, Wilkoff B, Canby RC, Schroeder JS, Liem LB, Hall S,
Wheelan K, For the Multi- center InSync ICD Randomized Clinical Evaluation (MIRACLE ICD) Trial Investigators (2003) Combined cardiac resynchronization and implantable cardioversion defibrillation in advanced chronic heart failure: the MIRACLE ICD Trial. JAMA 289:2685-2694

8. Saxon LA, Boehmer JP, Hummel J, Kacet S, De Marco T, Naccarelli G, Daoud E, For the VIGOR CHF and VENTAK CHF Investigators (1999) Biventricular pacing patients with congestive heart failure: two prospective randomized trials. Am J Cardiol 83:120D-123D

9. Packer M (2001) Proposal for a new clinical end point to evaluate the efficacy of drugs and devices in the treatment of chronic heart failure. J Card Fail 7:176-182

10. Bax JJ, Bleeker GB, Marwick TH, Molhoek SG, Boersma E, Steendijk P, van der Wall EE, Schalij MJ (2004) Left ventricular dyssynchrony predicts response and prognosis after cardiac resynchronization therapy. J Am Coll Cardiol 44:1834-1840

11. Yu CM, Fung JW, Zhang Q, Chan CK, Chan YS, Lin H, Kum LC, Kong SL, Zhang Y, Sanderson JE (2004) Tissue Doppler imaging is superior to strain rate imaging and postsystolic shortening on the prediction of reverse remodeling in both ischemic and nonischemic heart failure after cardiac resynchronization therapy. Circulation 110:66-73

12. Cazeau S, Bordachar P, Jauvert G, Lazarus A, Alonso C, Vandrell MC, Mugica J, Ritter P (2003) Echocardiographic modeling of cardiac dyssynchrony before and during multisite stimulation: a prospective study. Pacing Clin Electrophysiol 26(pt II):137-143

13. Notabartolo D, Merlino JD, Smith AL, DeLurgio DB, Vera FV, Easley KA, Martin RP, Leon AR (2004) Usefulness of the peak velocity difference by tissue Doppler imaging technique as an effective predictor of response to cardiac resynchronization therapy. Am J Cardiol 94:817-820

14. Søgaard P, Egeblad H, Pedersen AK, Kim WY, Kristensen BO, Hansen PS, Mortensen PT (2002) Sequential versus simultaneous biventricular resyn- chronization for severe heart failure: evaluation by tissue Doppler imaging. Circulation 106:2078-2084

15. Søgaard P, Egeblad H, Kim WY, Jensen HK, Pedersen AK, Kristensen BO, Mortensen PT (2002) Tissue Doppler imaging predicts improved systolic performance and reversed left ventricular remodeling during long-term cardiac resynchronization therapy. J Am Coll Cardiol 40:723-730

16. Chung ES, Leon AR, Tavazzi L, Sun JP, Nihoyannopoulos P, Merlino J, Abraham WT, Ghio S, Leclercq C, Bax JJ, Yu CM, Gorcsan J 3rd, St John Sutton M, De Sutter J, Murillo J (2008) Results of the predictors of response to CRT (PROSPECT) trial. Circulation 117(20):2608-2616 